\title{
Comparison of Increased Running Speed Using Resistance Parachute and Ladder Assisted Training Methods
}

\author{
$1^{\text {st }}$ Ketut Chandra Adinata Kusuma \\ Faculty of Sport and Health \\ Universitas Pendidikan Ganesha \\ Singaraja, Indonesia \\ chandra.adinata@undiksha.ac.id
}

\author{
$2^{\text {nd }}$ I Kadek Happy Kardiawan \\ Faculty of Sport and Health \\ Universitas Pendidikan Ganesha \\ Singaraja, Indonesia \\ happy.kardiawan@undiksha.ac.id
}

\author{
$3^{\text {rd }}$ I Made Satyawan \\ Faculty of Sport and Health \\ Universitas Pendidikan Ganesha \\ Singaraja, Indonesia \\ made.satyawan@undiksha.ac.id
}

\begin{abstract}
The running speed of football players can be increased through the method of resistance training with the help of tools. It is important to compare the effects on the use of different tools in the method. The purpose of this study was to determine the comparison of the increase in running speed using the resistance parachute and ladderassisted training methods. This research method is a quasi experimental research design with the modified pre testpost test group design. The number of subjects in this study were 20 amateur football players, who were divided into two groups using the ordinal pairing technique. The data collection technique uses a 30 meters sprint test to measure running speed. Data were analyzed using the independent ttest at a significance level of $5 \%$. The results of data analysis show that training using the resistance parachute has a better improvement than the use of the ladder on the running speed of amateur football players. Football coaches can use both training methods to increase the running speed of their players, especially the use of the resistance parachute assisted training method.
\end{abstract}

Keywords—resistance parachute, ladder, running speed.

\section{INTRODUCTION}

During the game of football we see three moments, namely moments of attack, moments of defense and transition [1]. The winning team is the team that is able to be effective when carrying out these three moments. Excellent physical condition is one of the main assets needed by every player if they want to be a winning team above. Apart from excellent cardiovascular endurance, every football player is also required to have high running speed and running acceleration.

Speed is the ability to cover a distance quickly [2]. The ability to move in a straight line or in a different direction / change direction is an integral part of all sports, including football. Speed is very dependent on strength because without strength, speed cannot be developed. If a student or athlete wants to develop his maximum speed then he must also develop his strength.

That at the farthest, football players will run only 10 or 20 meters [3]. This is because football players will not run very fast dribbling up to 100 meters or more. So that the speed of soccer players is different from ordinary sprinters. Even some positions, such as wing back, wing, and striker, are required to have more speed than players in different positions. But that doesn't mean other positions don't need running speed. During the game of football, players sprint on average around 17 meters and range from 5 to 50 or 60 meters [2]. So, the short speed and acceleration abilities that football players need to improve.

Various training methods are used to improve the performance and / or physical condition of football players. Especially for increasing running speed, the resistance training method has been tested by many experts. Upton tested differences in resistance sprinting methods and assistance sprints on running speed [4]. In resistance training, the perpetrators (athletes who train) use tools as weights or resistance such as using weights from other people's body weight, using elastic bands, parachutes, ladders, and running on an uphill surface (running up mountains).Training using a resistance parachute has a significant effect on increasing running speed [5] and the application of a ladder drill is an excellent training method to increase overall speed, coordination, agility, and power [6].

However, it has never been disclosed the comparison of the use of tools in resistance training methods to increasing running speed in football players. If you look at previous research on resistance parachute-assisted training methods that affect the running speed of futsal players [7] and the use of a ladder tool has also been shown to increase the running speed of futsal players [8], then this becomes interesting to reveal to football players. So the aim of this study was to determine the difference in the effect of training methods assisted by resistance parachute and ladder on the running speed of amateur football players.

\section{METHODS}

\section{A. Participants}

The research subjects were amateur football players who had a history of routine practice. The age of the subjects was in the range of 18 to 20 years, male. The subjects are all domiciled in Celukanbawang Village and have the status of Intan Jaya Celukanbawang club players. The number of subjects as many as 20 people who are the total players from the Intan Jaya club. The total subjects were divided into two groups with the same number using ordinal pairing techniques so that there was a similarity in quality between one training group and another. How to 
measure running speed during the pre test and post test using the 30 meter sprint test [9]. A tool for measuring the running time of each subject using the smart speed of fusion sports.

\section{B. Design and Data Analysis}

This research is a quantitative study using a quasi experimental research method with the modified pre-testpost-test group design [10]. After the subject was divided into two groups, each group consisting of 10 people. Group 1 was given the parachute resistance-assisted training method and group 2 was given the ladder-assisted training method. The exercise was undertaken three times a week for twelve meetings. During the pre test, practice and post test, the research subjects were obliged to wear soccer shoes. Furthermore, the data obtained were analyzed using the independent t-test with a significance level of 5\% assisted by the SPSS 16 program. Before the independent t-test was carried out, it was necessary to conduct a prerequisite test, namely the data normality test using the Kolmogorov-Smirnov test and continued with the homogeneity test. using the F test which aims to determine that the two groups have the same variance.

\section{RESULT}

Independent t-test test using a significance level $\alpha=$ 0.05. The significance value of the training method assisted by resistance parachute and ladder drill on running speed is 0.044 and 0.045 , with the sig $(0.044$ and $0.045)<\alpha(0.05)$ so that the hypothesis is accepted. So there is a difference in the speed of football players between those trained with the resistance parachute and the ladder. More details below are shown the test results table independent t-test.

TABLE I. INDEPENDENT T-TEST OF TRAINING METHODS ASSISTED BY RESISTANCE PARACHUTE AND LADDER DRILL ON RUNNING SPEED

\begin{tabular}{|c|c|c|c|c|c|c|c|c|c|c|}
\hline & & \multicolumn{2}{|c|}{$\begin{array}{c}\text { Levene's Test for } \\
\text { Equality of } \\
\text { Variances } \\
\end{array}$} & \multicolumn{7}{|c|}{ t-test for Equality of Means } \\
\hline & & \multirow[t]{2}{*}{$\mathrm{F}$} & \multirow[t]{2}{*}{ Sig. } & \multirow[t]{2}{*}{$\mathbf{t}$} & \multirow[t]{2}{*}{ df } & \multirow[t]{2}{*}{$\begin{array}{l}\text { Sig. (2- } \\
\text { tailed) }\end{array}$} & \multirow[t]{2}{*}{$\begin{array}{c}\text { Mean } \\
\text { Difference }\end{array}$} & \multirow{2}{*}{$\begin{array}{c}\text { Std. } \\
\text { Error } \\
\text { Differen } \\
\text { ce }\end{array}$} & \multicolumn{2}{|c|}{$\begin{array}{l}\text { 95\% Confidence } \\
\text { Interval of the } \\
\text { Difference }\end{array}$} \\
\hline & & & & & & & & & Lower & Upper \\
\hline \multirow[t]{2}{*}{$\begin{array}{c}30 \mathrm{~m} \\
\text { sprint } \\
\text { test }\end{array}$} & $\begin{array}{c}\text { Equal } \\
\text { variances } \\
\text { assumed } \\
\end{array}$ & .063 & .805 & 2,167 & 18 & .044 & .241 & .111 & .007 & .475 \\
\hline & $\begin{array}{c}\text { Equal } \\
\text { variances } \\
\text { not } \\
\text { assumed }\end{array}$ & & & 2,167 & 17,040 & .045 & .241 & .111 & .006 & .476 \\
\hline
\end{tabular}

\section{DISCUSSION}

Running speed is one of the main weapons of football players in every match. The characteristics of the running speed are different from other sports such as rugby, softball / baseball, or even futsal. Short speed and / or acceleration which is the main component in the running speed of football players. This is confirmed by Iswandiari's [3] statement which states that at the farthest, soccer players will run only 10 or 20 meters. Meanwhile, Bompa [2] stated that during the game of football, players sprint on average around 17 meters and range from 5 to 50 or 60 meters. For this reason, an effective training method will be able to realize the running speed needed by every football player.

Resistance training method is one of the effective training methods applied to increase the running speed of football players. Upton [4] who compared two training methods, namely the resistance sprinting method and assistance sprint to the running speed and acceleration of the IA division female soccer players. The results show that running training using the resistance sprinting method and assistance sprint both have a significant effect on running speed at a distance of 40 yards (36.6 meters). However, if you want to increase your acceleration at a distance of 5 - 15 yards (4.6 meters 13.7 meters), use the assistance sprint training method. If you want to increase the acceleration at a distance of 1525 yards (13.7 meters - 22.9 meters) and 25-40 yards (22.9 meters - 36.6 meters) then use the resistence sprinting method. So it is very relevant if the resistance sprinting method is applied to increase speed and acceleration which is clearly needed in the characteristics of the game of football. Resistance training methods often use various tools as a burden for athletes in training, including using resistance parachutes, resistance bands, ladders and many other tools.

However, the latest data have not been found on the difference or comparison of the results of the running speed of amateur football players who are given training methods assisted by resistance parachute with ladder. So from this study it was successful to reveal that the two methods were both successful in increasing running speed, but there were differences in results between those trained using the resistance parachute and the ladder. Based on the data and results above, the resistance training assisted training method is better than the ladder assisted training method. The resistance parachute assisted training method has the potential to increase muscle strength by overloading the body without sacrificing running kinematics and increasing shoulder flexion [11]. When running using the resistance parachute, resistance is applied just behind the center of the body and is caused by the air. Besides increasing endurance, training with a parachute will not change the athlete's own running technique. Whereas for training using the ladder trains the athlete's step speed when passing the ladder box on the ladder. So that training using the ladder will be more visible than its agility has been revealed by the speed Chandrakumar and Ramesh [12]. 


\section{CONCLUSION}

Based on the results and discussion above, the resistance parachute assisted training method has better results than the ladder assisted training method in increasing running speed. Although both of these training methods can increase the running speed of amateur football players. Referring to this conclusion, it is suggested that football coaches who want to increase the running speed of their players can use this training method.

\section{REFERENCES}

[1] Danurwindo, et al, Kurikulum Pembinaan Sepakbola Indonesia. Jakarta: Persatuan Sepakbola Seluruh Indonesia, 2017.

[2] Bompa, T.O and Buzzichelli, C.A, Periodization: Theory and Methodology of Training. New York University: IOWA, 2009.

[3] Iswandiari, Yuliati, "3 Teknik Sepak Bola Untuk Melatih Kelincahan," Downloaded from https://hellosehat.com/pusatkeseh/futsal trashed/teknik-sepak-bola-melatih-kelincahan/ [access date 11 December 2018].

[4] Upton, David E, The Effect of Assisted and Resisted Sprint Training On Acceleration and Velocity In Division IA Female Soccer Athletes, vol. 25. Journal Of Strength And Conditioning Research, 2011, pp. 2645-2652.
[5] Ridho, Moh. Ali, Pengaruh Latihan Dengan Menggunakan Parasut Terhadap Kecepatan Lari 60 M, vol. 3. Jurnal Prestasi Olahraga, 2018, pp. 1-7.

[6] Tsivkin, Troman, "Ladder Drill," Downloaded from http://www.sport-fitness-advisor.com. [access date 28 October 2012].

[7] Robid, Ahmad, Perbandingan Speed Training Parachute dengan Speed Resistance Band terhadap Peningkatan Kecepatan Lari Pada Pemain Futsal, vol. 2. Jurnal Prestasi Olahraga, 2019, pp. 15.

[8] Kusuma, K.C.A dan Kardiawan, I Kadek Happy, The effect of ladder drill exercise on speed, surrounding, and power leg muscle, vol. 6. ACTIVE: Journaal of Physical Education, Sport, Health, and Recreation, 2017, pp. 193-196.

[9] Mahardika, I Made Sriundy, "Pengantar Evaluasi Pengajaran," Surabaya: Unesa University Press, 2010.

[10] Kanca, I Nyoman, "Metode Penelitian Pengajaran Pendidikan Jasmani dan Olahraga," Singaraja: Universitas Pendidikan Ganesha, 2010.

[11] Paulson, Sally and Braun, William A, The Influence of ParachuteResisted Sprinting on Running Mechanics in Collegiate Track Athletes, vol. 25. Journal Of Strength And Conditioning Research, 2011, pp. $1680-1685$.

[12] Chandrakumar dan Ramesh, Effect of ladder drill and SAQ training on speed and agility among sports club badminton players, vol. 1. International Journal of Applied Research, 2015, pp. 527-529. 